ASM Sc. J., 13, 2020

https://doi.org/10.32802/asmscj.2020.sm26(1.13)

\title{
Modelling the Demand of Fresh Meat by Households in Malaysia
}

\author{
Nordiana Marjan Rusli1 ${ }^{*}$ and Assis Kamu ${ }^{1}$ \\ ${ }^{1}$ Faculty of Science and Natural Resources, Universiti Malaysia Sabah, Jalan UMS, 88400 Kota
} Kinabalu, Sabah

\begin{abstract}
There have been some changes in Malaysians' food preference as Malaysia is one of the most developing countries in Asia. These changes in consumption pattern have some impact on the agriculturally based food industry. One of the changes is in the preference for fresh meat such as poultry, beef, mutton, and other meat. This study is focusing on demand elasticity of fresh meat by households in Malaysia. This study has obtained demand elasticity of fresh meat via Linear Approximate Almost Ideal Demand System (LA-AIDS). Data from the Household Expenditure Survey (HES) 2014 has been used to build a statistical model in estimating the demand elasticity.
\end{abstract}

Keywords: demand elasticity; Linear Approximate Almost Ideal Demand (LA-AIDS); Household Expenditure Survey (HES) 2014

\section{INTRODUCTION}

The livestock industry is a very significant industry in Malaysia because of it responsible for the sources of protein (Fadhilah Annaim Huda, 2015). In addition, import of meat can be reduced due to the development of this industry. There have been some significant changes in food preference among consumers because Malaysia is one of the growing countries in Asia (Tey, 2008). These changes have some significant effect on preference towards poultry, beef, mutton, and other meat. This study will be focusing on the demand for poultry, fresh beef, and fresh mutton. The objective of this study is to estimate demand elasticities (i.e. price, cross price, and income) of fresh meatLinear Approximate Almost Ideal Demand System (LA-AIDS) approach.

Agricultural sector plays a part in Gross Domestic Product (GDP) in 2015 with 8.9\% (Department of Statistics Malaysia, 2016). Table 1 shows that the number of poultries rose to $1,613.9$ thousand tons in 2015 compared to 2014 which is $1,572.8$ thousand tons. On the other hand, the production of beef and mutton decreased to 50.50 thousand tons and 4.40 thousand tons respectively in 2015 compared to 52.90 thousand tons and 4.50 thousand tons respectively in 2014 . Table 2 shows the self-sufficiency level (SSL) of poultry, beef, and mutton in Malaysia from 2010 to 2015. It can be seen that SSL of poultry meat attained more than $100 \%$ which means that the local productions exceeded the local consumption. Meanwhile, SSL of beef decreased from 30.12\% in 2010 to $25.28 \%$ in 2014 while SSL of mutton rose to $12.74 \%$ in 2014 compared to 2010 which is $12.13 \%$.

Table 1. Productions of Livestock in 2014 and 2015

\begin{tabular}{|l|r|r|}
\hline $\begin{array}{c}\text { Livestock Products } \\
\text { ('ooo tons) }\end{array}$ & 2014 & 2015 \\
\hline Beef & 52.90 & 50.50 \\
\hline Mutton & 4.50 & 4.40 \\
\hline Pork & 217.60 & 215.80 \\
\hline Poultry & $1,572.80$ & $1,613.90$ \\
\hline Chicken/Duck egg & 727.60 & 775.10 \\
\hline Cattle Milk & 75.30 & 76.00 \\
\hline
\end{tabular}

(Source: Department of Veterinary Services Malaysia, 2016)

Table 2. Self-Sufficiency Level of Livestock Products in 


\begin{tabular}{|c|c|c|c|c|}
\hline \multicolumn{5}{|c|}{ Malaysia (\%) 2010-2015 } \\
\hline \multirow{2}{*}{ Year } & \multirow{2}{*}{ Region } & \multicolumn{3}{|c|}{ Livestock } \\
\hline & & Beef & Mutton & Poultry \\
\hline \multirow[t]{4}{*}{2010} & Malaysia & 30.12 & 12.13 & 105.55 \\
\hline & Peninsular & 31.10 & 12.41 & 106.86 \\
\hline & Sabah & 11.24 & n.a & 101.09 \\
\hline & Sarawak & 18.12 & 7.00 & 88.87 \\
\hline \multirow[t]{4}{*}{2011} & Malaysia & 29.17 & 11.73 & $105 \cdot 36$ \\
\hline & Peninsular & 30.02 & 11.94 & 106.27 \\
\hline & Sabah & 11.53 & n.a & 111.71 \\
\hline & Sarawak & 18.45 & 7.73 & 87.72 \\
\hline \multirow[t]{4}{*}{2012} & Malaysia & 28.26 & 19.71 & 104.88 \\
\hline & Peninsular & 29.60 & 20.08 & 105.84 \\
\hline & Sabah & 8.72 & n.a & 107.41 \\
\hline & Sarawak & 14.78 & 12.17 & 88.85 \\
\hline \multirow[t]{4}{*}{2013} & Malaysia & 25.66 & 15.51 & 104.85 \\
\hline & Peninsular & 27.22 & 16.54 & 105.91 \\
\hline & Sabah & 7.06 & n.a & 112.72 \\
\hline & Sarawak & 12.09 & 4.44 & 84.80 \\
\hline \multirow[t]{4}{*}{2014} & Malaysia & 25.28 & 12.74 & 104.30 \\
\hline & Peninsular & 26.69 & $13.5^{8}$ & 105.13 \\
\hline & Sabah & 7.47 & n.a & 119.49 \\
\hline & Sarawak & 12.14 & 3.84 & 83.44 \\
\hline \multirow[t]{4}{*}{$2015^{\mathrm{E}}$} & Malaysia & 23.50 & 11.46 & 104.48 \\
\hline & Peninsular & 24.80 & 12.22 & 105.04 \\
\hline & Sabah & 6.81 & n.a & 115.05 \\
\hline & Sarawak & 11.45 & 3.56 & 89.00 \\
\hline
\end{tabular}

\section{E: Estimates}

(Source: Department of Veterinary Services Malaysia, 2014)

\section{A. Estimating Demand Elasticities of Fresh}

\section{Meat}

Almost Ideal Demand System that was introduced by Deaton and Muellbauer (1980) has been widely used in food demand analysis. LA-AIDS is the linear form of AIDS. This demand model is very popular and often applied in demand analysis in Malaysia (Tey, 2008). Demand elasticities in this study consist of price elasticity, cross-price elasticity, and income elasticity. These elasticities are estimated using LAAIDS model as shown below:

$$
\begin{aligned}
& w_{i}=\alpha_{i}+\sum_{j} \gamma_{i j} \log \left(p_{j}\right)+\beta_{i} \log (x / P)+ \\
& \sum_{k} \gamma_{k} H_{k}+\theta_{i} i m r_{i}+\mu_{i}
\end{aligned}
$$

where $w_{i}$ expenditure share, $\alpha_{i}$ is constant, $\gamma_{i j}$ is slope coefficient, $p$ is price, $\beta_{i}$ are elasticities , $x$ is an aggregate total expenditure, $\gamma_{k}$ is slope household, $H_{k}$ is household size and dummy, $i m r_{i}$ is inverse Mill ratio and $\mu_{i}$ is a random disturbance.

Demand elasticities of LA-AIDS can be computed from Green and Alston (1990) formulae as shown below:

Marshallian price elasticities:

$$
e_{i j}^{L A-A I D S}=-\delta_{i j}+\left(\frac{\gamma_{i j}}{\overline{w_{l}}}\right)-\left(\frac{\beta 1_{i}}{\overline{w_{l}}}\right) \overline{w_{J}}
$$

where $\delta_{i j}$ is Kronecker delta which is unity if $i=j$ and zero otherwise. Meanwhile, income elasticities of LA-AIDS come from the formulae of Chern (2000) and can be computed as follows:

Income elasticities

$$
\eta_{i}^{L A-A I D S}=\left(\frac{\partial x}{\partial X} \frac{X}{x}\right) * e_{i}^{L A-A I D S}
$$

where $X$ is the total expenditure of fresh meat and $x$ is the total expenditure of aggregate fresh meat.

The LA-AIDS model from equation (1) can be transformed into isoelastic demand function by transforming both dependent and independent variables into logarithmic value as shown in equation (4):

Isoelastic demand function

$$
\log w=\alpha_{i}+\beta_{i} \log X_{i}+\cdots+\mu
$$

wherew is expenditure share on fresh meat, $\alpha_{i}$ is constant, $\beta_{i}$ are elasticities, $X_{i}$ is explanatory variables and $\mu$ is a random error. Meanwhile, the hypothetical demand model for fresh meat to be estimated using LA-AIDS is shown below:

$\log \llbracket w=\beta \_0 \rrbracket+\beta \_1 \log P P+\beta \_2 \log P B+$

$\beta \_3 \log P M+\beta \_4 \log I+\beta \_5 \log H+\beta \_6 S L+\mathbb{\beta} \rrbracket$

_7 $S R+\beta \_8 S+\beta \_9 E H+\beta \_10 N H+\beta \_11 E P+\beta \_12 E S+$

$\beta \_13 E T+\mu$

where $w$ is expenditure share on fresh meat, $P P$ is retail price of poultry, $P B$ retail price of fresh beef, $P M$ retail price of fresh mutton, $I$ is household income, $H$ is the number of households, $S L$ is area of Sabah and Federal Territory of Labuan, $S R$ area of Sarawak, $S$ strata, $E H$ is ethnicity of 
household head, $N H$ is nationality of household head, EP is the education level of household head (primary), ES is education level of household head (secondary), ET is the education level of household head (tertiary) and $\mu$ is random error.

\section{METHODOLOGY}

Data from Household Expenditure Survey (HES) 2014 conducted by the Department of Statistics Malaysia is used to build a statistical model in estimating the demand elasticities of fresh meat (Department of Statistics Malaysia, 2015). This survey has 14,838 number of households. This study uses Statistical Package for the Social Science (SPSS) software to analyze the data. Dependent variables in this study are expenditure share on poultry meat, expenditure share on fresh beef and expenditure share on fresh mutton whereas the independent variables consist of retail price of poultry meat, retail price of fresh beef, retail price of fresh mutton, household income, location, strata and sociodemographic characteristics (i.e. ethnic, nationality and education level). The demand elasticities are estimated using LA-AIDS.LAAIDS is performed simultaneously for each independent variable.

\section{RESULTS AND DISCUSSIONS}

This section provides results and discussions of results.

\section{A. Demand Elasticities of Fresh Meat}

The parameter estimates of LA-AIDS model is presents in Table 3 below. Sociodemographic factors such as the area of Sabah and Federal Territory of Labuan, area of Sarawak, ethnicity of household head, nationality of household head and education level of household head (secondary and tertiary) have some significant effect on expenditure share of poultry, fresh beef, and fresh mutton. There are no direct economic interpretations of the magnitude of socio demographic characteristics coefficients, but its sign can tell the direction of the relationship between a dependent variable and independent variables (Osei-Asare \& Eghan, 2013).

Table 3. Parameter Estimates of LA-AIDS Model

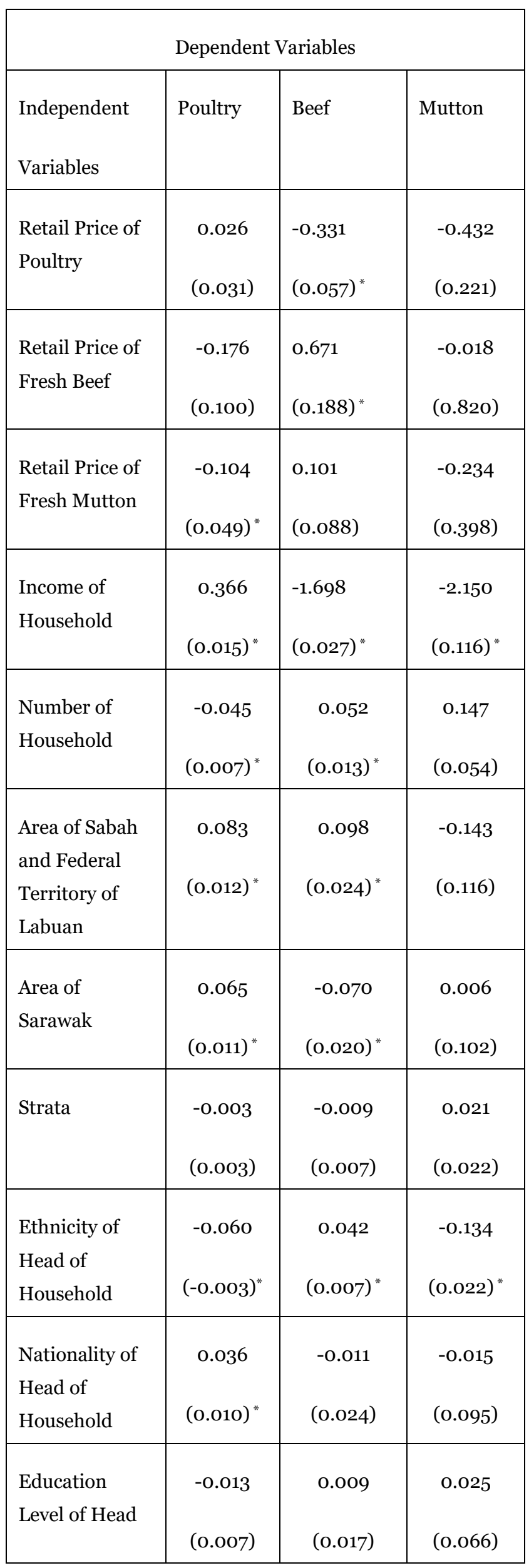




\begin{tabular}{|l|c|c|c|}
\hline $\begin{array}{l}\text { of Household } \\
\text { (Primary) }\end{array}$ & -0.025 & 0.012 & 0.073 \\
\hline $\begin{array}{l}\text { Education } \\
\text { Level of Head } \\
\text { of Household } \\
\text { (Secondary) }\end{array}$ & $(0.007)^{*}$ & $(0.016)$ & $(0.062)$ \\
\hline $\begin{array}{l}\text { Education } \\
\text { Level of Head } \\
\text { of Household } \\
\text { (Tertiary) }\end{array}$ & -0.039 & 0.025 & 0.086 \\
\hline
\end{tabular}

the value of elasticities of -0.104 and -0.337 respectively which is smaller than 1 . Hence, this implying that there is less response of one commodity to change in the price of another commodity. Besides, beef-mutton pair has a negative sign, but it is not significant. However, Taljaard et al. (2004) found that the pair of chicken-mutton pair carry positive sign which means there are substitute commodities.

Next, income elasticity of poultry is 0.336 which is it is a normal good and thus, when income rise, the demand for poultry meat will increase. It means that an increase in $1 \%$ of income will increase the expenditure share on poultry by 0.366\%. Meanwhile, fresh beef and fresh mutton are inferior Standard errors are in parentheses, and

* denotes significant at 0.05 significance level

goods because the values of elasticities are -1.698 and -2.150 respectively. Thus, when the income of consumers increases, the demand for fresh beef and fresh mutton will fall which

In keeping with Table 3 above, for poultry equation, a number of households, area of Sabah and Federal Territory of Labuan, area of Sarawak, the ethnicity of household head, the nationality of household head and education level of household head (secondary and tertiary) are statistically significant. Area of Sabah and Federal Territory of Labuan, area of Sarawak and ethnicity of the household head have a positive relationship with expenditure share of poultry meat while others have a negative relationship.

The factors that have a significant influence on the expenditure share of fresh beef are a number of households, area of Sabah and Federal Territory of Labuan, area of Sarawak and ethnicity of the household head. All of the factors have a positive relationship with expenditure share except the area of Sarawak and the most influential factor is the number of households. For fresh mutton equation, the ethnicity of the household head is statistically significant at 0.05 significance level and it has a negative relationship with the expenditure share of fresh mutton.

Price elasticity of poultry and fresh beef demand is not consistent with the demand theory as it has a positive sign which is 0.0260 .671 respectively. This could be because of correlation or data limitation (Zhou, 2015). On the other hand, price elasticity of fresh mutton demand is negative, but it is not statistically significant. Osei-Asare and Eghan (2013) found that price elasticity of meat demand is negative and highly elastic which is consistent with demand theory. A study conducted by Taljaard et al. (2004) also found that chicken and mutton carry negative signs and relatively inelastic. For cross-price elasticity, poultry-mutton pair and mutton-beef are complement commodities because it has a negative sign. Poultry-mutton pair and beef-poultry pair have means that an increase in $1 \%$ of income will reduce the demand for fresh beef and fresh mutton by $-1.698 \%$ and $2.150 \%$ respectively. According to Tey et al. (2008), meat is a normal good and consumers are expected to increase their consumption on meat. Since the expenditure share sum to 1 for the major meat equations, so they are homogeneous of degree zero in prices and satisfy the symmetry. Hence, all the restrictions imposed on LA-AIDS model are satisfied.

\section{SUMMARY}

The central focus of this study is to estimate the demand elasticities of poultry, fresh beef, and fresh mutton via LAAIDS model. Sociodemographic characteristics such as number of households, area of Sabah and Federal Territory of Labuan, ethnicity of household head and education level of household head (secondary and tertiary) have significant influence on the demand of poultry whereas the factors that influence the expenditure share of fresh meat are number of households, area of Sabah and Federal Territory of Labuan, area of Sarawak and ethnicity of household head. For fresh mutton equation, the only ethnicity of the household head has a significant effect on the expenditure of fresh mutton. This study finds that poultry is a normal good (positive income elasticity) while fresh beef and fresh mutton are inferior good (negative income elasticity). Next, poultrymutton pair and beef-poultry pair are compliment commodities due to their negative sign. Price elasticity of poultry and fresh beef have a positive sign which is not consistent with the demand theory. 


\section{ACKNOWLEDGEMENTS}

First and foremost, very much gratitude to Department of Statistics Malaysia for providing data of Household Expenditure Survey 2014 and a heartfelt thanks to Department of Veterinary Services Malaysia for providing the price of poultry meat for 2014. Lastly, a very special appreciation to those who being so helpful throughout the process of this study.

\section{REFERENCES}

Chern, W.S. 2000, Assesment of Demand - Side Factors Affecting Global Food Security. In Chern, W.S., Carter, C.A. and Shei, S.Y. eds. Food Security in Asia: Economics and Policies. Chestenham, UK: Edward Elgar Publishing Limited. Ch. 6.

Deaton, A. \& Muellbaeur, J. 1980, An Almost Ideal Demand System. The American Economic Review, 70, 312-326.

Department of Statistics Malaysia. 2016, Distribution of GDP by Kind of Economic Activity (https://www.dosm.gov.my/v1/index.php?r=column/cthe meByCat\&cat=159\&bul_id=eDg2NolTWGxTd3JzTlpwMX FUejRydzo9\&menu_id=TE5CRUZCblh4ZTZMODZIbmk2 aWRRQTo9).Accessed on 2 April 2017.

Department of Veterinary Services Malaysia. 2015, Malaysia: Self-Sufficiency in Livestock Products (\%), 2006-2015 (www.dvs.gov.my/dvs/resources/user_1/DVS\%2opdf/Per angkaan/\%202014/2014_2015/kadar_sara_diri_Muka Surat_1-15.pdf). Accessed on 30 March 2017.

Department of Veterinary Services Malaysia. 2016, Livestock $\begin{array}{llll}\text { Population } & 2014 & \& & 2015\end{array}$ (www.dvs.gov.my/dvs/resources/user_1/DVS\%2opdf/Per angkaan\%202142015/2014_2015/bil_ternakan_20140215Muka_Surat_115.pdf).Accessed on 30 March 2017.

Fadhilah Annaim Huda, H. 2015, Strategies to Strengthen Livestock Industry in Malaysia. FFTC Agricultural Policy Articles, 1-6.

Green, R. \& Alston, J.M. 1990, Elasticities in AIDS Models. American Journal of Agricultural Economics, 72(2), 442445 .
Osei-Asare, Y.B. \& Eghan, M. 2013, The Effects of Food Price Increases on Urban Households Food Commodities Expenditure in Ghana. Journal of Economics and Sustainable Development, 4(6).

Taljaard, P.R., Alemu, Z.G., \& Schalkwyk van H.D. 2004, The Demand for Meat in South Africa: An Almost Ideal Estimation. Agrekon, 43(4).

Tey, Y.S. 2008. Demand for Beef in Malaysia: Preference for Quantity, Quality or Lean? International Food Research Journal, 15(3), 347-353.

Tey, Y.S., Mad Nasir, M., Zainalabidin, M. \& Amin Mahir, A. 2008, Demand Analysis of Food in Malaysia: A Study of Malay Ethnic. Munich Personal RePEc Archieve. 